\title{
ASAS KEBIASAAN PEMBERIAN UANG PANJAR DALAM TRANSAKSI JUAL BELI ERA PASAR BEBAS*
}

\author{
Holijah $^{* *}$
}

Hukum Bisnis, Fakultas Syariah dan Hukum, UIN Raden Fatah Palembang

Jalan Prof. K.H. Zainal Abidin Fikry No. 1 KM. 3,5 Palembang 30126

\begin{abstract}
Recently, the activities of economic and as well as various model of transaction has always been developed. However the transaction with this system (voorschot) always happened in the society. This research is aiming to give a concept and practice by consequences of law from a custom giving a voorschot in transaction. This research is using a documentary and library research. The result of this study showed that with a concept and practice of giving voorschot who is recognized by positive law as well as customary law, civil law and islamic law. Then in the development of the practice this transaction of buying a product with this system is approved as a sign of agreement and can be allowed to held it.
\end{abstract}

Keyword: transaction, voorschot, custom.

\section{Intisari}

Pemberian uang panjar dalam transaksi jual beli suatu produk barang adalah merupakan kebiasaan yang terjadi di masyarakat Indonesia. Transaksi jual beli produk barang sebagai upaya dalam memenuhi kebutuhan dan cara mendistribusikan kebutuhan, yang mana konsep dan praktiknya melandaskan pada filosofi yang berbeda-beda. Pemberian uang panjar sebagai konsep perjanjian, adalah selaras dengan asas kebiasaan dalam perjanjian, sehingga uang panjar sebagai uang tanda jadi dan uang muka dalam transaksi jual beli produk barang juga dalam praktik tergantung kesepakatan akan di kembalikan atau tidak, termasuk bagian harga jual ataupun tidak. Sementara itu, mengenai pemberian uang panjar sebagai uang muka jika terjadi pembatalan, maka uang panjar sebagai uang muka dikembalikan.

Kata kunci: produk barang, uang muka, uang tanda jadi.

\section{Pokok Muatan}

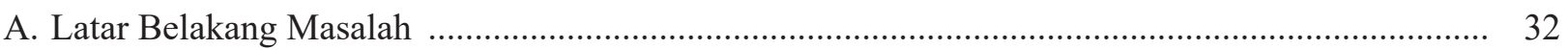

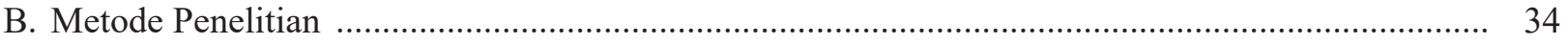

C. Hasil Penelitian dan Pembahasan .................................................................................................. 34

1. Perspektif Jual Beli dalam Hukum Positif Indonesia ............................................................. 34

2. Perkembangan Penerapan Asas Kebiasaan Pemberian Uang Panjar sebagai Tanda Jadi dan sebagai Uang Muka dalam Transaksi Jual Beli Produk Barang ........................................ 36

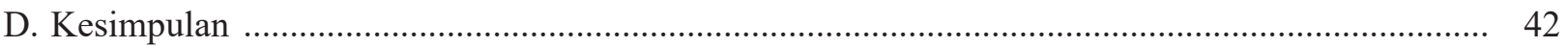




\section{A. Latar Belakang Masalah}

Masyarakat dalam mencapai taraf hidup lebih baik dari sisi ekonomi, sosial maupun sisi lainnya tidak terlepas peran strategis dari adat istiadat dan kebiasaan yang berkembang dalam masyarakat itu sendiri. ${ }^{1}$ Demikian juga dalam memenuhi kebutuhan dan cara mendistribusikan kebutuhan, namun demikian tidak terlepas pada filosofi yang berbedabeda yang terjadi akibat perbedaan keyakinan agama, ideologi, budaya hukum, dan kepentingan politik dari suatu komunitas masyarakat tertentu. ${ }^{2}$

Keberadaan pelaku usaha dalam rangkaian kegiatan ekonomi yang dilakukan baik pada masa memproduksi, maupun pendistribusian produk yang dihasilkan adalah tidak terlepas dari perilaku homo economicus dari gaya hidup (life style) pelaku usaha dan pola perilaku konsumsi (patterns of consumption) dari konsumen. Untuk itu perlu normanorma untuk menghindari terjadinya pelanggaranpelanggaran dalam kegiatan bisnis yaitu untuk mendapatkan keuntungan sebesar-besarnya dari kegiatan bisnis yang dilakukan pelaku usaha. Oleh sebab itu, pentingnya perlindungan hukum bagi konsumen sebagai satu konsep terpadu, ${ }^{3}$ mengingat era pasar bebas saat ini. Pasar bebas adalah suatu kebebasan kodrati dan keadilan, atau merupakan perwujudan hukum kodrat dalam bidang ekonomi. ${ }^{4}$ Hal ini karena realitasnya dalam kegiatan ekonomi di mana etika berbisnis yang sehat sering diabaikan, namun tindakan merugikan merupakan hal yang biasa dilakukan.

Prinsipnya setiap kegiatan ekonomi yang dilakukan termasuk dalam jual beli tidak boleh salah satu pihak konsumen ataupun pelaku usaha, dalam hal ini terutama konsumen yaitu pembeli sebagai pihak lemah cenderung untuk dirugikan. Transaksi jual beli yang di awali dengan pemberian uang panjar, merupakan bentuk transaksi yang sudah menjadi kebiasaan di lakukan. Artinya transaksi jual beli dengan pemberian uang panjar juga dapat berimplikasi rentannya pihak pembeli untuk dirugikan.

Transaksi jual beli antara penjual dan pembeli harus di dasarkan pada rasa saling, terutama berkaitan dengan kesepakatan mengenai keadaan objek yang diperjualbelikan. Selain itu penjual dan pembeli juga harus menyepakati akibat dari pemberian uang panjar dalam transaksi jual beli tersebut. Rasa saling percaya dapat tumbuh dari ketaatan masyarakat pada norma-norma hukum dan norma-norma sosial yang berkembang dalam kehidupan kemasyarakatan yang sesuai nilai moral dalam pandangan agama dan menjadi dasar karakter baik dalam pandangan dunia. ${ }^{6}$

Pemberian uang panjar $^{7}$ dapat terjadi secara lisan maupun secara tertulis, yang mana dalam Kitab Undang - Undang Hukum Perdata (KUHPerdata) merupakan suatu bentuk perjanjian yang merupakan bagian dari perikatan dalam Buku ke III KUHPerdata. Perikatan adalah hubungan hukum yang terjadi antara dua orang atau lebih, yang terletak dalam lapangan hukum harta kekayaan, di mana pihak yang satu berhak atas prestasi dan pihak lainnya wajib memenuhi prestasi itu. ${ }^{8}$

Tidak semua perikatan harus dinyatakan secara tegas, apabila menurut kebiasaan selamanya dianggap di per-janji-kan sebagaimana termaktub dalam Pasal 1347 KUHPerdata. Meskipun tidak dinyatakan secara tegas, para pihak pada dasarnya mengakui syarat-syarat adanya hak dan kewajiban,

M. Ali Amin, et al, 2001, Kompilasi Adat Istiadat Sumatera Selatan, Pemerintah Sumatera Selatan, Palembang, hlm. iii.

Zainuddin Ali, 2008, Hukum Ekonomi Syariah, Sinar Grafika, Jakarta, hlm. 1.

Holijah, 2014, "Pengintegrasian Urgensi dan Eksistensi Tanggung Jawab Mutlak Produk Barang Cacat Tersembunyi Pelaku Usaha dalam Undang - Undang Perlindungan Konsumen di Era Globalisasi”, Jurnal Dinamika Hukum, Vol. 14 No. 1 Januri 2014, hlm. 177.

A. Sonny Keraf, 1996, Pasar Bebas Keadilan dan Peran Pemerintah Telaah Atas Etika Ekonomi Adam Smith, Kanisius, Yogyakarta, hlm. 198. Romli Atmasasmita, 2010, Globalisasi Kejahatan Bisnis, Edisi Kedua, Cetakan Ke-1, Kencana Prenada Media Group, Jakarta, hlm. 76. M. Umer Chapra, 2008, Reformasi Ekonomi: Sebuah Solusi Perspektif Islam, PT. Bumi Aksara, Jakarta, hlm. 62

Panjar dalam bahasa Arab adalah al 'urbuun. Kata ini memiliki persamaan kata (sinonim) al urbaan, al 'urbaan dan al-urbuun. Riska Aini, 2017, "Praktek Jual Beli Tanah dengan Memakai Uang Panjar (Uang Muka) di Kecamatan Laguboti Kabupaten Tobasa Propinsi Sumatera Utara (Perspektif Fikih As-Syafi'i dan Fikih Al-Hanbali)", Skripsi, Program Sarjana Fakultas Syari'ah dan Hukum UIN Sumatera Utara, Medan, hlm. 3.

8 Mariam Darus Badrulzaman, et al, 2016, Kompilasi Hukum Perikatan, Citra Aditya Bakti, Jakarta, hlm. 1. 
karena memberi akibat komersial terhadap maksud para pihak. Adapun hal yang harus diperhatikan adalah mengenai kewajiban yang tidak dinyatakan secara tegas dari suatu perikatan yang timbul dari keadaan yang tidak ada ketentuan yang tegas mengenai persoalan tersebut. ${ }^{9}$

Pasal 1339 KUHPerdata menjelaskan bahwa adanya kesepakatan tidak hanya mengikat yang dinyatakan secara tegas oleh para pihak, akan tetapi juga meliputi segala sesuatu yang menurut perjanjian, diharuskan oleh kepatutan, kebiasaan dan undang-undang. Kebiasaan yang di maksud adalah kebiasaan pada umumnya (gewoonte) yaitu kebiasaan setempat atau kebiasaan yang lazim yang berkembang dalam masyarakat tertentu. ${ }^{10}$ Memperhatikan Pasal 1347 dan 1339 KUHPerdata, transaksi jual beli dengan pemberian uang panjar adalah dapat dilakukan berdasarkan kebiasaan yang biasa di lakukan dalam masyarakat atau golong tertentu. Keberadaan uang panjar ini, yang mana maksud dari uang panjar adalah berupa uang pembayaran sejumlah uang yang berfungsi sebagai tanda jadi pemesanan dengan maksud konsumen benar-benar akan membeli produk barang yang di jual pelaku usaha. ${ }^{11}$

Proses yang sering terjadi dalam jual beli sebelum serah terima objek yang diperjualbelikan adalah memberikan panjar (persekot/voorschot) sebagai tanda jadi. Hukum adat panjar atau persekot adalah merupakan pemberian sejumlah uang yang diterima penjual dan pembeli. ${ }^{12}$ Mengenai transaksi jual beli ini juga termuat dalam bunyi Pasal 1464 KUHPerdata, jika pembelian dilakukan dengan memberi uang panjar, maka salah satu pihak tak dapat membatalkan pembelian itu dengan menyuruh memiliki atau mengembalikan uang panjarnya. ${ }^{13}$

Sementara itu, menurut Fatwa DSN MUI Nomor 04/DSN-MUI/IV/2000 tentang Murabahah, Pasal 7 dinyatakan bahwa jika uang muka memakai kontrak 'urbun (uang panjar) sebagai alternatif, maka:

a. jika nasabah memutuskan untuk membeli barang tersebut, ia tinggal membayar sisa harga; dan

b. jika nasabah batal membeli, uang muka menjadi milik bank maksimal sebesar kerugian yang ditanggung oleh bank akibat pembatalan tersebut; dan jika uang muka tidak mencukupi, nasabah wajib melunasi kekurangannya.

Pemahaman pelaksanaan dan akibat dari pemberian uang panjar dari penjual dan pembeli sangat urgen mengetahui kebiasaan yang di lakukan dalam masyarakat. Risiko dari adanya pihak yang dirugikan dari perikatan jual beli yang menggunakan sistem pemberian uang panjar baik yang didahului adanya perjanjian tertulis maupun tidak tertulis. Sesuai perkembangan bentuk transaksi jual beli akibat kemajuan teknologi dan era pasar bebas, maka transaksi jual beli dengan sistem pemberian uang panjar dapat terjadi secara langsung ataupun tidak langsung seperti jual beli secara on-line. Jika pengetahuan serta pemahaman pembeli tentang kebiasaan yang berkaitan dengan transaksi jual beli dengan sistem panjar sangat sedikit akan sangat memungkinkan akan merasa tidak adil, jika kemudian pembeli merasa dirugikan dengan hilangnya uang panjar telah di berikan kepada penjual. Keadilan bersifat adil terbuka, tidak khusus untuk golongan tertentu. Artinya seorang muslim dapat menetapkan keadilan untuk orang non muslim. ${ }^{14}$

Indonesia sebagai negara hukum, memandang konsep keadilan adalah persamaan dan persamaan itu akan diperoleh melalui hukum, karena semua hal yang didasarkan kepada hukum dapat dianggap sebagai adil, (lex injusta no nest lex) hukum yang tidak adil bukanlah hukum. ${ }^{15}$

\footnotetext{
Titik Triwulan Tutik, 2011, Hukum Perdata dalam Sistem Hukum Nasional, Prenada Media Group, Jakarta, hlm. 235. Ibid., hlm. 236.

Antari Innaka, et al, "Penerapan Asas Itikad Baik", Mimbar Hukum, Volume 24 Nomor 3, Oktober 2012, hlm. 506.

Hilman Hadikusuma, 2003, Pengantar Ilmu Hukum Adat Indonesia, Mandar Maju, Bandung, hlm. 225.

Subekti dan R. Tjitrosudibio, 2009, Kitab Undang-Undang Hukum Perdata, Cet. Ke-9, PT. Pradnya Paramita, Jakarta, hlm. 367.

Arifinsyah, 2010, Alquran dan Harmonitas Antariman, Citapustaka Media Perintis, Bandung, hlm. 143.

Bahder Johan Nasution, 2011, Negara Hukum dan Hak Asasi Manusia, Mandar Maju, Bandung, hlm. 98-99.
} 
Selaras dengan pendapat Aristoteles, menyatakan bahwa kata adil mengandung makna lebih dari satu. Adil dapat berarti menurut hukum dan apa yang sebanding, yaitu yang semestinya. ${ }^{16}$ Tidak adanya aturan tertulis yang tertuang dalam undang-undang, bagaimana pengaturan tentang keberadaan uang panjar termasuk juga akibat adanya uang panjar dalam suatu transaksi ekonomi termasuk dalam transaksi jual beli. Oleh sebab itu, berlandaskan konsep dan praktik tentang uang panjar dalam hukum adat, hukum Islam dan hukum perdata yang merupakan agent of change, yang dapat dijadikan sebagai sarana mendidik masyarakat ke arah hukum dari masyarakat itu sendiri, sehingga hukum bisa memberikan kepastian yang berkeadilan yang bermanfaat mengayomi manusia.

Berlandaskan pada latar belakang yang dijelaskan di atas, maka menarik untuk di kaji lebih lanjut tentang praktik pemberian uang panjar, baik sebagai uang tanda jadi dan uang panjar sebagai uang muka. Ini penting dalam upaya perlindungan konsumen dalam melakukan transaksi jua beli agar terhindar dari kerugian karena tidak memahami konsep dan praktik hukum uang panjar. Untuk itu, perlu penjelasan yang komprehensif terkait dengan (1) Bagaimanakah perspektif jual beli dalam hukum positif Indonesia dan (2) Bagaimanakah perkembangan penerapan asas kebiasaan pemberian uang panjar dalam transaksi jual beli produk barang berupa benda atas penggunaan istilah uang panjar.

\section{B. Metode Penelitian}

Penelitian ini menggunakan metode penelitian kepustakaan atau studi dokumen atau dengan istilah metode penelitian yuridis normatif yaitu suatu bentuk penelitian yang datanya diperoleh dari pustaka yang lazimnya dilakukan terhadap data yang bersifat sekunder, ${ }^{17}$ dengan menggunakan sumber-sumber dokumen yang ada kaitannya dengan penelitian yang dikombinasi dengan hasil penelitian yang pernah dilakukan oleh penulis juga. Adapun tujuan penelitian adalah (1) Menjelaskan dan menganalisis perspektif jual beli dalam hukum positif Indonesia dan (2) Menganalisis perkembangan penerapan asas kebiasaan pemberian uang panjar dalam transaksi jual beli produk barang berupa benda atas penggunaan istilah uang panjar.

\section{Hasil Penelitian dan Pembahasan \\ 1. Perspektif Jual Beli dalam Hukum Positif Indonesia}

Jual beli adalah merupakan kegiatan tolong menolong antara sesama manusia mempunyai landasan yang amat kuat dalam Islam, baik dari Alquran, Sunah dan Ijmak. Para ulama fikih berijmak bahwa hukum dari jual beli adalah mubah (boleh). Pemikiran hukum jual beli yang membolehkan, tidak terlepas kedudukan manusia sebagai makhluk sosial yang saling membutuhkan satu sama lain, karena fungsi dari jual beli itu sendiri adalah untuk dapat membantu dalam kelangsungan hidup manusia. Meskipun demikian, menurut Imam al-Syațibi mengatakan bahwa hukum jual beli bisa berubah dari mubah menjadi wajib dalam situasi tertentu.

Masyarakat hukum adat menentukan bahwa masalah transaksi jual beli mempunyai sifat kontan (tunai) dan percaya yang kuat dan tidak secara tertulis. Adapun maksud kontan (tunai) adalah suatu bentuk prestasi yang dilakukan sekaligus bersamasama pada waktu itu juga. ${ }^{18}$ Sementara mengenai sifat percaya yang kuat adalah saling percaya satu sama lain antara pembeli dan penjual, sehingga walaupun sudah ada kata sepakat antara kedua belah pihak itu, namun belum terjadi jual beli.

Menurut hukum perdata dalam perjanjian jual beli memiliki ketentuan, yaitu, jual beli sudah terjadi apabila sudah terucap kata sepakat, meskipun objek dari jual beli belum di serahkan dan harganya belum di bayar. Selanjutnya dalam

\footnotetext{
S. Tasrif, 1987, Bunga Rampai Filsafat Hukum, Abardin, Jakarta, hlm. 97.

Suratman, et al, 2013, Metode Penelitian Hukum, Alfabeta, Bandung, hlm. 51.

Iman Sudiyat, 2010, Asas-Asas Hukum Adat Bekal Penghantar, Liberty, Yogyakarta, hlm. 153.
} 
transaksi jual beli menurut Hukum Perdata, mengharuskan untuk membuat suatu bukti tertulis sebagai ketentuan yang sudah ditetapkan untuk masalah pembuktian sebagaimana tertuang dalam pasal 1458 KUHPerdata.

Ada perbedaan sistem dalam transaksi jual beli antara hukum adat dan hukum perdata. Hukum adat dalam jual beli tidak terjadi hanya karena ada kata sepakat saja. Hukum perdata dalam perjanjian jual beli memiliki ketentuan, yaitu jual beli sudah terjadi apabila sudah terucap kata sepakat, meskipun barang tersebut belum di serahkan dan harganya belum di bayar. Sementara dalam hukum adat, dalam transaksi jual beli yang terpenting adalah penyerahan objeknya. Hal ini memperlihatkan perbedaan sistim jual beli antara hukum adat dan hukum perdata. Hukum adat dalam jual beli tidak terjadi hanya karena ada kata sepakat saja.

Jual beli dalam hukum perdata merupakan bentuk perjanjian yang mana perjanjian merupakan juga bagian hukum perikatan. Istilah perikatan berasal dari bahasa Belanda, yaitu verbintenis. Istilah verbintenis di Indonesia di kenal dalam tiga istilah, yaitu (1) Perikatan; (2) Perutangan; (3) Perjanjian. ${ }^{19}$ Secara terminologi, verbintenis berasal dari kata verbinden yang artinya mengikat, sehingga diartikan menunjuk kepada adanya ikatan atau hubungan. ${ }^{20}$ Adapun yang di maksud dengan perjanjian jual beli (koop en verkoop) adalah suatu persetujuan antara dua pihak, di mana pihak pertama berjanji akan menyerahkan suatu barang dan pihak kedua akan membayar harga yang telah disetujui. Sementara itu, menurut hukum Islam, jual beli secara etimologi adalah berasal dari bahasa Arab al-bai' yang artinya tukar menukar sesuatu dengan sesuatu yang lain. ${ }^{21}$ Secara umum jual beli menurut hukum Islam adalah tukar menukar harta dengan harta menurut cara yang khusus, harta mencakup zat (barang) atau uang. ${ }^{22}$ Kesimpulannya jual beli adalah peristiwa pertukaran harta di bidang perdagangan yang di miliki dengan cara yang sesuai dengan ketentuan atau cara tertentu yang memberikan manfaat bagi kedua belah pihak. ${ }^{23}$

Perubahan hukum yang menjadi syarat-syarat pembentukan hukum harus benar-benar berlanjut berlaku ke dalam kehidupan masyarakat ke dalam perhubungan hukum manusia. Perbandingan hukum juga menganalisis relasi antara struktur hukum, aturan hukum, dan masyarakat di mana ketiganya beroperasi. ${ }^{24}$ Hukum adalah senantiasa suatu penyusunan yuridis suatu masyarakat pada tempat dan waktu yang tertentu, struktur dan kebutuhankebutuhan riil masyarakat akan menentukan dan membatasi kemungkinan-kemungkinan dalam pembentukan hukum yang sesungguhnya. ${ }^{25}$

Selanjutnya, yang menjadi objek dari jual beli adalah apa yang di sebut dengan benda atau barang dan jasa beserta turunannya. Objek jual beli ini dalam hukum Islam di kenal dengan istilah dengan ma'qud 'alaih. Macam-macam benda dapat dibagibagi dalam berbagai kategori sebagai berikut:

a. Benda bergerak dan benda tidak bergerak;

b. Benda berwujud dan benda tidak berwujud;

c. Benda yang dapat di bagi dan benda yang tidak dapat dibagi;

d. Benda yang sudah ada dan benda yang akan ada;

e. Benda yang dapat dihaki secara pribadi dan benda milik umum;

f. Benda yang dapat dihabiskan dan benda yang tidak dapat dihabiskan. ${ }^{26}$

Adapun objek dalam transaksi jual beli dalam tulisan adalah berupa semua jenis benda dan produk

\footnotetext{
Titik Triwulan Tutik, Op.cit., hlm. 195.

Setiawan, 1999, Pokok-Pokok Hukum Perikatan, Putra Arbardin, Jakarta, hlm. 1.

Wahbah Zuhaili, 1989, Al-Fiqh Al-Islamiy Wa Adillatuh, Juz IV, Dar Al-Fikr, Damskus, hlm. 344.

Ali Fikri, 1357 H, Al-Mu'amalat Al-Maddiyah wa Al-Adabiyah, Juz 2.Cet I; Mathba'ah Mushthafa Al-Babiy Al-Halabiy, Mesir, hlm. 9.

Holijah, 2017, Analisis Hukum Uang Panjar terhadap konsep dan Praktik Ganti Rugi dalam Transaksi Jual Beli Produk Barang Ekonomi Modern di Indonesia, Noerfikry Refress, Palembang, hlm. 26.

Alan Watsons, "Comparative Law and Legal Change", The Cambridge Law Journal, Vol. 37, No. 2, November 1978., hlm. $313-336,315$.

R. Van Dijk, 2006, Pengantar Hukum Adat Indonesia, Mandar Maju, Bandung, hlm. 95

Munir Fuady, 2014, Konsep Hukum Perdata, PT, RajaGrafindo Persada, Jakarta, hlm. 29.
} 
barang. Adapun yang dimaksudkan dengan produk barang tersebut adalah:

Setiap barang baik berwujud maupun tidak berwujud, baik bergerak maupun tidak bergerak, dapat dihabiskan maupun tidak dapat dihabiskan, yang dapat untuk diperdagangkan, dipakai, dipergunakan, atau dimanfaatkan oleh konsumen yang berupa bahan mentah yang telah melalui proses kimiawi atau turunannya maupun hasil olahan yang dibuat dan ditambah gunanya atau nilainya dalam suatu proses produksi sebelum dikomersialkan. ${ }^{27}$

Kemudian, dalam perkembangannya transaksi jual beli produk barang ini mengalami perkembangan baik secara bentuk dari pada akad dari transaksi itu sendiri yaitu dilakukan secara tertulis melalui akta jual beli ataupun secara lisan yang berdasarkan pada unsur saling percaya satu sama lain. Kemudian juga dari sistim pembayarannya yang dapat berupa pemberian uang panjar ataupun tidak.

\section{Perkembangan Penerapan Asas Kebiasaan Pemberian Uang Panjar sebagai Tanda Jadi dan sebagai Uang Muka dalam Transaksi Jual Beli Produk Barang}

Analisa hukum jual beli di Indonesia dapat dilakukan dengan berlandaskan pada hukum adat, hukum perdata dan hukum Islam. Dalam masyarakat Hukum Adat, masalah perikatan jual beli adalah bersifat kontan (tunai) dan percaya yang kuat. Maksud kontan (tunai) adalah suatu bentuk prestasi yang dilakukan sekaligus bersama-sama pada waktu itu juga. Sementara mengenai sifat percaya yang kuat adalah saling percaya satu sama lain yaitu antara pembeli dan penjual dalam proses jual beli tersebut. ${ }^{28}$

Proses transaksi jual beli menurut hukum adat tidak secara tertulis, karena tidak membuat bukti tertulis yang disebabkan oleh ada saling percaya baik dari pihak pembeli ataupun dari pihak penjual. Memperhatikan pelaksanaan jual beli dalam hukum adat jual beli bukan merupakan perjanjian jual beli, melainkan berupa penyerahan benda oleh penjual kepada pembeli. Ini menunjukkan bahwa dalam hukum adat dari transaksi jual beli adalah penyerahan barang bukan kata sepakatnya.

Praktik jual beli dalam masyarakat adat yang menggunakan sifat kontan (tunai) dan percaya, dalam perkembangannya pada praktik adalah juga ada di lakukannya perjanjian jual beli menurut hukum perdata yaitu di awali dengan perjanjian secara tertulis. Menurut hukum perdata dalam perjanjian jual beli memiliki ketentuan, bahwa jual beli telah terjadi dari adanya kata sepakat, meskipun objek jual beli itu belum diserahkan sama pembeli. Selanjutnya dalam perjanjian jual beli dalam hukum perdata, mengharuskan untuk membuat suatu bukti tertulis sebagai ketentuan yang sudah ditetapkan untuk masalah pembuktian sebagaimana tertuang dalam pasal 1458 KUHPerdata.

Perbedaan sistem jual beli antara hukum adat dan hukum perdata terlihat jelas dalam penjelasan di atas. Hukum adat dalam jual beli tidak terjadi hanya karena ada kata sepakat saja. Hukum perdata dalam jual beli yang termaktub dalam Pasal 1458 KUHPerdata yang berbunyi, jual beli dianggap telah terjadi antara kedua belah pihak, segera setelah orang-orang itu mencapai kesepakatan tentang barang tersebut beserta harganya, meskipun barang itu belum diserahkan dan harganya belum dibayar.

Sementara itu, dalam hukum Islam mengenai keberadaan jual beli itu sendiri adalah dihalalkan dan dibenarkan, asal memenuhi syarat-syarat yang diperlukan disepakati para ahli ijmak (ulama' mujtahidin) dan tidak ada khilaf padanya. ${ }^{29}$ Jual beli dengan sistem pemberian uang panjar dalam hukum

\footnotetext{
27 Holijah, 2015, Tanggung Jawab Mutlak Ascetisisme Responsif Subjektif Pelaku Usaha: Konsep Radikal Berbasis Paradigma Hukum Baru sebagai Alternatif Upaya Perlindungan Konsumen terhadap Kerugian Akibat Produk Barang Cacat Tersembunyi di Indonesia, Disertasi, PPS Ilmu Hukum UNSRI, Palembang, hlm. 113.

28 Iman Sudiyat, 2010, Asas-Asas Hukum Adat Bekal Penghantar, Liberty, Yogyakarta, hlm. 153.

29 Umi Maghfuroh, 2010, Tinjauan Hukum Islam terhadap Status Uang Muka dalam Perjanjian Pesanan Catering yang di Batalkan, Skripsi, Fakultas Syari'ah IAIN Walisongo, Semarang, hlm.4.
} 
Islam ${ }^{30}$ ada pendapat, yaitu menurut pandangan Hanafiyyah, Malikiyyah, dan Syafiiyyah bahwa jual beli dengan pemberian uang panjar adalah tidak sah, karena jenis jual beli jenis ini termasuk memakan harta orang lain dengan cara bathil, di mana disyaratkan bagi si penjual tanpa ada kompensasinya. Selain itu, dalam jual beli dengan sistem pemberian uang panjar ada dua syarat bathil yaitu syarat memberikan panjar dan syarat mengembalikan barang transaksi dengan perkiraan salah satu pihak tidak ridha. ${ }^{31}$

Adapun syarat-syarat jual beli dengan sistem uang panjar, menurut Majelis Fikih Islam adalah sebagai berikut: ${ }^{32}$

a. Apabila pemberian uang panjar dimaksud sebagai muka dalam menjual suatu produk barang, lalu si pembeli memberi sejumlah uang kepada si penjual dengan syarat bila pembeli jadi mengambil barang tersebut, maka uang muka tersebut masuk dalam harga yang harus dibayar. Namun kalau si pembeli tidak jadi membelinya, maka sejumlah uang (muka yang dibayarkan) tersebut menjadi milik penjual. Pemberian uang panjar ini berlaku juga untuk sewa menyewa, karena menyewa berarti membeli fasilitas. Jual beli dengan sistem uang panjar ini tidak diperbolehkan apabila memiliki syarat harus ada serah terima pembayaran atau barang transaksi di lokasi akad (jual beli as-salm) atau serah terima keduanya (barter komoditi riba fadhal dan money changer). Selain itu juga tidak diperbolehkan dalam transaksi jual beli murabahah tidak berlaku bagi orang yang mengharuskan pembayaran pada waktu yang dijanjikan, namun hanya pada fase penjualan kedua yang dijanjikan.;

b. Pemberian uang panjar dalam transaksi jual beli dibolehkan bila waktu menunggunya dibatasi secara pasti. Uang panjar tersebut dimasukkan sebagai bagian pembayaran, jika sudah dibayar lunas dan menjadi milik penjual bila si pembeli tidak jadi melakukan transaksi pembelian.

Pemberian uang panjar dalam transaksi jual beli mempunyai fungsi sebagai berikut: ${ }^{33}$

a. Menunjukkan kesungguhan pembeli, yang sekaligus mendorong penjual untuk tidak menjual kembali;

b. Menutupi risiko yang ditanggung penjual dan sebagai biaya kesempatan atau kerugian lain yang muncul seandainya jual beli gagal dilakukan di kemudian hari.

Memperhatikan fungsi dari pemberian uang panjar ini, maka pola dan risiko dari adanya pemberian uang panjar dalam transaksi jual beli akan terus berkembang. Perkembangan tersebut tentunya akan sangat mendorong dari proses transaksi jual beli itu yang diharapkan akan mempermudah seseorang untuk mendapatkan suatu produk barang yang diinginkan. Namun demikian, tetap harus ada pedoman yang jelas dalam menerapkan prosedural transaksi jual beli dengan sistim pemberian uang panjar ini. Hal ini antara lain adalah untuk menghindari adanya pihak yang dirugikan.

Transaksi jual beli suatu produk barang adalah perkara penting yang harus mendapatkan perhatian besar di era perdagangan pasar bebas saat ini. Pemberian uang panjar dalam transaksi produk barang juga selalu akan berkembang, untuk itu

\footnotetext{
30 Hukum Islam adalah Kaidah, asas, prinsip atau aturan yang digunakan untuk mengendalikan masyarakat Islam, baik berupa ayat Al-Qur'an, hadist Nabi SAW. Pendapat sahabat dan tabi'in maupun pendapat yang berkembang di suatu masa dalam kehidupan umat Islam". Atau koleksi dari hukum Syari'at yang berkaitan dengan perbuatan yang digali dari dalil-dalil yang terperinci., Abdul Azis Dahlan, 1997, Ensiklopedi Hukum Islam, Jilid II, Ichtiar Baru Van Hoeve, Jakarta, h. 575-576.

Abdullah al-Mushlih, 2001, Fiqih Ekonomi Keuangan Islam, Darul Haq, Jakarta, hlm.132-133.

32 Abdullah, Al-Mushlih, Shalah Ash-Shawi, 2014, Fiqih Ekonomi Keuangan Islam, Darul Haq, Jakarta, hlm. 134.

33 M. Sobirin Asnawi, et al, 2007, Hukum Keuangan Islam: Konsep, Teori dan Praktik, Nusamedia, Bandung, hlm. 189.
} 
pemahaman masyarakat sebagai konsumen sangat penting untuk memahami hukum uang panjar. Uang panjar dalam transaksi sesuai syariat Islam merupakan sejumlah uang yang dibayarkan di muka oleh seseorang pembeli barang kepada si penjual. ${ }^{34}$ Istilah panjar ini menunjukkan ada kecenderungan bahwa panjar itu diartikan sebagai tanda jadi, yang di dalamnya terselip unsur saling percaya mempercayai antara para pihak. ${ }^{35}$ Sementara yang dimaksud dengan uang panjar secara umum adalah sejumlah uang yang berfungsi sebagai tanda jadi, sehingga pemberian panjar tidak berhak untuk mengambil kembali uang panjar tersebut.

Perkembangan praktik pemberian uang panjar saat ini, telah membagi uang panjar ke dalam dua kategori yaitu: (a) uang panjar sebagai uang tanda jadi atau; dan (b) uang panjar sebagai uang muka (down payment/DP). Pengetahuan tentang perbedaan kategori dari kedua kategori tersebut sangat di perlukan dalam proses penerapan hukum yang akan di lakukan jika terjadi kerugian bagi salah satu pihak baik bagi pembeli atau penjual.

Sistem pemberian uang panjar dalam jual beli di hukum adat adalah belum terjadi serah terima objek jual beli, yang mana di lakukan kesepakatan dari kedua belah pihak, yaitu pembeli menyerahkan panjar berupa persekot (voorschot) sebagai tanda jadi dalam bentuk sejumlah uang. Persekot sebagai pembayaran pendahuluan dari pembeli kepada penjual yang di sebut sebagai uang panjar akan di potong dari pembayaran harga ketika pelunasan pembayaran yang dilakukan. Akibat hukum panjar sebagai persekot dalam hukum adat ini adalah akan dapat hilang apabila perjanjian batal karena kesalahan dari pihak pembeli, dan apabila tidak dinyatakan dalam kesepakatan awal maka persekot dikembalikan kepada penjual apabila perjanjian tidak dilanjutkan oleh pihak penjual.

Implikasi pemberian uang panjar juga dapat di lihat pada Pasal 56 Kompilasi Hukum Adat
Istiadat Kota Palembang, yang menjelaskan tentang pembatalan perjanjian adat yang diikuti dengan pemberian panjar tidak dapat di laksanakan/batal, maka berlaku ketentuan: ${ }^{36}$

a. Apabila pembatalan perjanjian adat itu di lakukan oleh pemberi panjar, maka panjar itu tidak dikembalikan oleh penerima panjar atau di selesaikan sesuai dengan adat istiadat setempat;

b. Apabila pembatalan perjanjian itu di lakukan oleh penerima panjar, maka penerima, maka panjar itu dikembalikan oleh penerima panjar sesuai dengan perjanjian atau sesuai dengan adat setempat.

Berlandaskan pada Pasal 1464 KUHPerdata, maka yang di maksud dalam pasal ini panjar yang di maksud adalah sebagai tanda jadi, sehingga uang panjar yang telah di berikan oleh pembeli kepada penjual tidak dapat di ambil atau dikembalikan kepada pembeli jika jual beli tersebut batal. Praktiknya dari perkembangan Pasal 1464 KUHPerdata ini adalah sebagai uang tanda jadi dan uang muka, panjar tidak bisa atau dapat di tolak untuk pengembalian dalam hal terjadi pembatalan secara sepihak. Memperhatikan perkembangan dari praktik dari pemberian uang panjar dalam sistem hukum adat dan hukum perdata sebagaimana tersebut di atas juga dapat melihat jual beli dengan sistem panjar menurut hukum Islam. Para jumhur ulama mempunyai perbedaan pendapat mengenai jual beli dengan sistem panjar ini, yaitu: (a) pihak yang melarang/mengharamkan; dan (b) pihak yang membolehkan.

Dasar hukum jumhur ulama dari pendapat pertama yang melarang/mengharamkan bahwa jual beli dengan sistem panjar/urbun itu haram, karena di dalamnya dianggap terdapat ghoror dan jahalah, yaitu ketidakjelasan. Artinya dengan panjar tersebut belum memperjelas kedudukan

M. Sobirin Asnawi, et al, Loc.cit.

Holijah, 2017, Op.cit., hlm.39.

36 Pemerintahan Provinsi Sumatera Selatan, 2001, Kompilasi Adat Istiadat Kota Palembang, Meru, Pemerintah Provinsi Sumatera Selatan, hlm. 39. 
jual beli tersebut terjadi atau pun tidak, sehingga terlarang yang berakibat pada haram hukumnya. Pendapat kedua mengatakan bahwa jual beli urbun itu sah dan boleh-boleh saja. Hal ini dapat di lihat dari pendapat 'Umar, Ibnu 'Umar dan Imam Ahmad yang menganggap bahwa ketidakjelasan pada transaksi jual beli dengan pemberian uang panjar ini adalah bukan merupakan ketidakjelasan mengenai keinginan untuk membeli atau tidak. Selain itu, pembeli dapat membatalkan untuk membeli setelah pemberian uang panjar, namun dengan memberikan ganti rugi, sehingga jual beli 'urbun di perbolehkan. Keberadaan uang panjar dari jual beli dalam hukum Islam berfungsi sebagai uang pengikat (persekot) bukti kesepakatan dan tidak dikembalikan lagi kecuali telah diperjanjikan sebelumnya.

Fatwa DSN MUI Nomor 04/DSN-MUI/ IV/2000 tentang Murabahah, pada Pasal 7, menyatakan bahwa, jika uang muka memakai kontrak 'urbun (uang panjar) sebagai alternatif, maka: (1) jika nasabah memutuskan untuk membeli barang tersebut, ia tinggal membayar sisa harga; (2) jika nasabah batal membeli, uang muka menjadi milik bank maksimal sebesar kerugian yang ditanggung oleh bank akibat pembatalan tersebut; dan jika uang muka tidak mencukupi, nasabah wajib melunasi kekurangannya.

Selaras dengan perkembangan transaksi jual beli produk barang dengan sistem pemberian uang panjar sebagai tanda jadi dan pemberian uang panjar sebagai uang muka. Uang panjar sebagai tanda jadi biasa terjadi dari transaksi jual beli yang mana yang terjadi sebelum akad, sementara itu, uang panjar sebagai uang muka yang terjadi setelah penyerahan objek jual beli atau sudah terjadi akad jual beli sempurna, adalah tetap berhak untuk menuntut ganti rugi. Undang - Undang Perlindungan Konsumen telah menjamin kepastian hukum bagi pembeli untuk menuntut ganti rugi yaitu hak untuk mendapatkan kompensasi, ganti rugi dan atau/ penggantian, apabila barang dan atau jasa yang di terima tidak sesuai dengan perjanjian atau tidak sebagaimana mestinya. Pasal 4 huruf (h) mengenai tuntutan ganti rugi Undang - Undang Perlindungan Konsumen.

Hak bagi penjual atau pembeli dapat menuntut ganti rugi jika merasa dirugikan, akan tetapi sepanjang dapat membuktikan kerugian yang di alami untuk dapat menuntut ganti rugi sebagaimana tersebut adalah adil baik bagi penjual maupun bagi pembeli. Untuk itu harus ada tidak ada iktikad baik dan kejujuran bagi pihak yang mengajukan tuntutan ganti rugi. Untuk itu adalah adil untuk menuntut ganti rugi, di mana seharusnya karakter yang melekat pada keadilan adalah adil, bersifat hukum, sah menurut hukum, tidak memihak, sama hak, layak, wajar secara moral dan benar secara moral. ${ }^{37}$ Namun demikian, dengan batasan bahwa selama konsumen dapat membuktikan bahwa kerugian yang di derita adalah akibat dari pelaku usaha, yang dapat berupa: ${ }^{38}$

a. Produk barang yang diperjualbelikan ternyata cacat hukum, artinya bahwa produk barang adalah milik orang lain, hasil dari tindak kejahatan yang tidak diketahui oleh pembeli;

b. Produk barang cacat tersembunyi yang tidak diketahui oleh pembeli;

c. Adanya pembatalan secara sepihak dari penjual atau pembeli.

Pemberian uang panjar dalam transaksi jual beli suatu produk barang dapat berupa sebagai tanda jadi atau sebagai uang muka ini, kedua-duanya menjadi dimasukkan ke dalam harga pembayaran juga tidak dapat menjadi bagian harga pembayaran yang mana ini dalam praktiknya berbeda-beda. Hal ini pun di dukung juga bahwa pola kehidupan yang kompleks dari perkembangan peradaban saat ini. Dalam memenuhi kebutuhan dan cara mendistribusikan kebutuhan, manusia melandaskan pada filosofi yang berbeda-beda, di antaranya akibat perbedaan keyakinan agama, ideologi, 
budaya hukum, dan kepentingan politik dari suatu komunitas masyarakat tertentu. ${ }^{39}$

Jual beli dengan sistem panjar sesungguhnya sangat rentan untuk terjadinya kerugian, kejujuran dan iktikad baik kedua belah pihak memang patut diperhatikan dalam praktik jual beli dengan sistem pemberian uang panjar. Hal ini karena sebagaimana dijelaskan sebelumnya juga dapat dari kemungkinan dari konsep dan praktiknya adalah seorang pembeli membayar sejumlah uang kepada penjual sejumlah uang yang lebih sedikit dari nilai harga produk barang dari harga produk barang tersebut setelah selesai transaksi, untuk jaminan barang.

Sesungguhnya kebiasaan dalam pemberian uang panjar dari dalam transaksi jual beli dalam masyarakat ini jika ditilik lebih jauh sebagai suatu perjanjian. Untuk pemberian uang panjar dibenarkan secara hukum yang mana dapat di lihat dalam Pasal 1339 KUHPerdata jo Pasal 1347 KUHPerdata bahwa perjanjian tidak hanya mengikat untuk apa saja yang secara tegas di atur, akan tetapi juga halhal yang dalam kebiasaan dan lazim diikuti yaitu kebiasaan yang berkembang dalam kehidupan masyarakat, yaitu sesuai dengan kebiasaan dari masing-masing hukum adat yang berlaku. ${ }^{40}$

Pasal 1339 KUHPerdata menyatakan bahwa suatu persetujuan tidak hanya mengikat untuk halhal yang secara tegas dinyatakan di dalamnya, tetapi juga segala sesuatu yang menurut sifat persetujuan diharuskan oleh kepatutan, kebiasaan dan Undang - Undang. Kemudian Pasal 1347 KUHPerdata yang menyatakan bahwa hal-hal yang menurut kebiasaan diperjanjikan dianggap secara diam-diam di masukan di dalam perjanjian meskipun tidak dengan tegas dinyatakan. Asas kebiasaan sebagai salah satu asas dalam suatu perikatan merupakan hasil lokakarya BPHN tahun 1985, ada delapan (8) asas yaitu:
a. Asas kepercayaan;
b. Asas persamaan hukum;

c. Asas keseimbangan

d. Asas kepastian hukum;

e. Asas moral;

f. Asas kepatutan;

g. Asas kebiasaan;

h. Asas perlindungan.

Asas kebiasaan digunakan dalam suatu transaksi jual beli termasuk transaksi jual beli dengan adanya pemberian uang panjar, maka makna asas kebiasaan pemberian uang panjar dalam jual beli suatu produk barang adalah bahwa hal-hal yang menurut kebiasaan biasa terjadi dalam praktik bermasyarakat selama ini yang berlaku adalah sebagai bentuk persetujuan atau perjanjian. Meskipun tidak dengan tegas dinyatakan, pemberian uang panjar sebagai bentuk persetujuan yang dinyatakan secara diam-diam adalah peristiwa hukum persetujuan karena kebiasaan, baik sebagai kebiasaan umum maupun sebagai kebiasaan setempat. Artinya pemberian uang panjar sebagai bentuk persetujuan yang bersumber dari kebiasaan yang timbul dari transaksi jual beli, jika dinyatakan secara tegas maka tunduk pada perjanjian tertulis.

Risiko dari pemberian uang panjar sebagai kebiasaan umum adalah sesuai dengan kebiasaan dalam peristiwa jual beli pada umumnya yaitu tergantung kebiasaan biasanya terjadi dari peristiwa pemberian uang panjar dari objek yang sama atau sesuai kebiasaan dalam praktik dari masyarakat setempat yang biasa terjadi dalam praktiknya. Dalam hukum adat secara umum yaitu sebagai pengikat dari sepakat yang menjadi persekot atau tanda jadi, sementara itu pemberian uang panjar sebagai kebiasaan setempat adalah dengan melihat kebiasaan dari praktik dari masyarakat tempat pelaksanaan transaksi jual beli dengan pemberian uang panjar tersebut, seperti masyarakat Hukum Adat Sumatera Selatan atau daerah lain. Hal ini dikarenakan adat istiadat dan kebiasaan masyarakat tersebut menjadi perilaku sosial budaya atau yang

39 Zainuddin Ali, 2008, Hukum Ekonomi Syariah, Sinar Grafika, Jakarta, hlm. 1.

40 Van Vollenhoven mengidentifikasikan setidaknya terdapat 19 wilayah hukum adat di Indonesia selama kurun waktu 1906-1908. Franz Von Benda-Beckmann, et al., "Myths And Stereotypes About Adat Law: A Reassessment Of Van Vollenhoven In The Light Of Current Struggles Over Adat Law In Indonesia", .Bijdragen Tot De Taal- Land- En Volkenkunde, Vol. 167, No. 2/3, 2011, hlm. 167-195, $173-174$. 
disebut dengan kebudayaan. Ini menjadi peluang hakim dalam menyelesaikan sengketa dalam menggali hukum tidak tertulis untuk kemudian menjadi dasar hukum dalam menyelesaikan suatu sengketa. ${ }^{41}$

Kebiasaan pemberian uang panjar di Sumatera Selatan tersebut dapat di lihat pada Pasal 56 Kompilasi Hukum Adat Istiadat Kota Palembang, apabila terjadi perjanjian adat yang diikuti dengan pemberian panjar tidak dapat di laksanakan/batal, maka berlaku ketentuan: (a) Apabila pembatalan perjanjian adat itu di lakukan oleh pemberi panjar, maka panjar itu tidak dikembalikan oleh penerima panjar atau di selesaikan sesuai dengan adat istiadat setempat; (b) Apabila pembatalan perjanjian itu di lakukan oleh penerima panjar, maka penerima, maka panjar itu dikembalikan oleh penerima panjar sesuai dengan perjanjian atau sesuai dengan adat setempat. ${ }^{42}$

Oleh karena itu, dalam perkembangan dari pemberian uang panjar secara konsep dan praktiknya adalah kemungkinan dari konsep dan praktik jual beli dengan sistem pemberian uang panjar dalam jual beli adalah sebagai tanda jadi yaitu sudah menjadi kebiasaan yang berkembang dalam masyarakat. Pemberian uang panjar ini adalah dilakukan sebagai tanda jadi, dengan ketentuan apabila jual beli ini di lanjutkan, maka bagi pembeli, uang panjar sebagai uang muka tersebut terhitung dalam bagian pembayaran dan bila tidak melanjutkan jual beli tersebut, maka penjual berhak mengambil uang panjar tersebut.

Selanjutnya, dalam perkembangan saat ini juga terjadi kecenderungan bahwa pemberian uang panjar ini di jadikan sebagai sarana untuk pemasaran suatu produk barang melalui pembelian secara kredit. Pemberian uang panjar sebagai sarana promosi ini adalah salah satu yang memudahkan seseorang untuk mendapatkan suatu produk barang dengan hanya menyerahkan batasan jumlah minimal harga dari harga sesungguhnya. Menurut Peraturan Menteri Keuangan (PMK) Nomor 43/ PMK.010/2012 tentang Uang Muka Pembiayaan Konsumen Untuk Kendaraan Bermotor pada Perusahaan Pembiayaan disebutkan bahwa aturan pemberian uang panjar sebagai uang muka minimal adalah 20\%, meskipun dalam kenyataan di lapangan yang terjadi uang panjar sebagai uang muka adalah $10 \%$ dan bahkan ada sampai $0 \% .{ }^{43}$ Hal ini menunjukkan pemberian uang panjar sebagai uang muka untuk produk barang berupa hasil produksi.

Memperhatikan konsep dan praktik pemberian uang panjar baik sebagai tanda jadi maupun sebagai uang muka, terlihat bahwa adanya maksud untuk melakukan transaksi jual beli itu secara sempurna yaitu terjadinya jual beli bagi kedua belah pihak. Di sisi lain juga memperlihatkan bahwa adanya pemberian panjar adalah sebagai jaminan berupa tanda jadi dari adanya kesepakatan untuk transaksi jual beli, maka apabila terjadi pembatalan uang panjar sebagai jaminan itu menjadi hak penjual. Namun jika tidak terjadi pembatalan transaksi, maka uang panjar sebagai jaminan itu akan menjadi bagian dari harga produk barang itu secara keseluruhan. Pemberian uang panjar ini adalah sebagai bentuk hak pilih baik bagi penjual maupun pada pembeli untuk kemudian akan meneruskan atau membatalkan transaksi jual beli.

Meskipun ada perbedaan pada transaksi tunai yaitu di mana pada transaksi jual beli dengan sistem panjar ini, penjual diberi sebagian dari pembayaran apabila barang dikembalikan, karena nilainya telah berkurang bila orang mengetahui hal ini. Pada sisi penjual sistem ini akan menjadikan pembeli yang telah menyerahkan uang tanda jadi akan termotivasi untuk menyempurnakan transaksi jual belinya dan bagi pembeli, mempunyai kesempatan untuk memilih mengembalikan barang tersebut.

\footnotetext{
Choky R. Ramadhan, "Konvergensi Civil Law dan Common Law di Indonesia dalam Penemuan dan Pembentukan Hukum”, Mimbar Hukum, Volume 30, Nomor 2, Juni 2018, hlm. 227.

42 Pemerintahan Provinsi Sumatera Selatan, Loc.cit

43 Anindya Mutiara, Ida Fatmawati, Indah Permatasari, "Problematika Penerapan Prosentase Down Payment (Uang Muka) Sebesar 20 \% Pada Kredit Kendaraan Bermotor", Jurnal Private Law, Edisi 1 Maret-Juni 2013, hlm.6.
} 
Pembelian produk barang dengan sistem panjar berupa pemberian uang panjar sebagai tanda jadi atau di kenal dengan istilah booking fee merupakan bagian dari harga. Apabila terjadi pembatalan maka uang panjar dapat hangus. Selanjutnya, jika pemberian uang panjar adalah sebagai uang muka, maka jika terjadi pembatalan akan di kembalikan kepada pembeli. Selanjutnya, dalam praktiknya uang panjar sebagai tanda jadi terjadi sebelum terjadi akad jual beli secara tertulis sedangkan uang panjar sebagai uang muka adalah setelah terjadinya akad jual beli.

Uang panjar sebagai tanda jadi dalam transaksi jual beli produk barang juga terjadi dalam praktik tergantung kesepakatan akan di kembalikan atau tidak, termasuk bagian harga jual ataupun tidak. Sementara itu, mengenai pemberian uang panjar sebagai uang muka jika terjadi pembatalan, maka uang panjar sebagai uang muka dikembalikan. Namun, uang panjar sebagai tanda jadi dan sebagai uang muka ada persamaannya adalah bahwa uang panjar tersebut di hitung sebagai bagian dari harga keseluruhan produk barang yang diperjualbelikan.

Berdasarkan pada ketentuan hukum yang berlaku dan praktik di masyarakat menunjukkan keberadaan uang panjar dalam transaksi produk barang di era modern saat ini tidak dapat dihindari selain memang sudah menjadi kebiasaan di masyarakat Indonesia. Iktikad baik dan kejujuran adalah hal penting dalam melakukan kegiatan ekonomi termasuk dalam transaksi jual beli produk barang dengan sistem uang panjar. Hal ini, sangat selarasnya dari fungsi dari adanya pemberian uang panjar sebagai jaminan bagi kedua belah pihak. Selain itu, pembeli dan penjual telah membuktikan keinginan yang kuat untuk melakukan transaksi jual beli. Selanjutnya diharapkan ada perubahan paradigma bagi para pelaku bisnis bahwa dalam mencari keuntungan melalui jual beli produk barang harus yakni mempunyai prinsip bahwa dalam mencari rezeki harus berkah, yang salah satunya tidak boleh merugikan orang lain.

\section{Kesimpulan}

Berdasarkan pembahasan di atas maka disimpulkan bahwa, Pertama, menurut perspektif jual beli dalam hukum positif Indonesia bahwa Transaksi jual beli saat ini terus berkembang baik dari jenis media yang berupa konvensional atau melalui elektronik ataupun teknik pelaksanaan yaitu secara lisan ataupun tertulis. Pada hukum adat dalam jual beli tidak terjadi hanya karena ada kata sepakat saja tetapi setelah ada penyerahan objek berbeda dengan hukum perdata yang menyatakan jual beli telah terjadi setalah ada kata kesepakatan. Dalam hukum Islam masalah jual beli adalah merupakan pertukaran harta dalam bidang perdagangan.

Kedua, perkembangan penerapan asas kebiasaan pemberian uang panjar dalam transaksi jual beli produk barang berupa benda adalah dapat dilakukan dan disandarkan pada kebiasaan, sehingga tergantung pada kesepakatan dari penjual dan pembeli. Uang panjar saat berkembang menjadi uang tanda jadi dan uang muka. Uang panjar sebagai tanda jadi biasa terjadi dari transaksi jual beli yang mana yang terjadi sebelum akad, sementara itu, uang panjar sebagai uang muka yang terjadi setelah penyerahan objek jual beli atau sudah terjadi akad jual beli sempurna. Apabila pemberian uang panjar terjadi sebelum ada penyerahan dari produk barang yang dijadikan objek jual beli, maka apabila dari pihak penjual dan beli dapat membatalkan transaksi, terutama apabila salah satu pihak merasa dirugikan dari adanya transaksi jual beli yang dilakukan. Pemberian uang panjar dalam transaksi jual beli suatu produk barang berupa dapat berupa sebagai tanda jadi atau sebagai uang muka ini, kedua-duanya menjadi dimasukkan ke dalam harga pembayaran juga tidak dapat menjadi bagian harga pembayaran tergantung kesepakatan dan kebiasaan setempat. 


\section{DAFTAR PUSTAKA}

\section{A. Buku}

Amin, M. Ali, et al, 2001, Kompilasi Adat Istiadat Sumatera Selatan, Pemerintah Sumatera Selatan, Palembang.

Ali, Zainuddin, 2008, Hukum Ekonomi Syariah, Sinar Grafika, Jakarta.

Atmasasmita, Romli, 2010, Globalisasi Kejahatan Bisnis, Edisi Kedua, Cetakan Ke-1, Kencana Prenada Media Group, Jakarta.

Arifinsyah, 2010, Alquran dan Harmonitas Antariman, Citapustaka Media Perintis, Bandung.

Al-Mushlih, Abdullah, 2001, Fiqih Ekonomi Keuangan Islam, Darul Haq, Jakarta.

Al-Mushlih, Abdullah, Shalah Ash-Shawi, 2014, Fiqih Ekonomi Keuangan Islam, Darul Haq, Jakarta

Badrulzaman, Mariam Darus, et al, 2016, Kompilasi Hukum Perikatan, Citra Aditya Bakti, Jakarta.

Chapra, M. Umer 2008, Reformasi Ekonomi: Sebuah Solusi Perspektif Islam, PT. Bumi Aksara, Jakarta.

Dahlan, Abdul Azis 1997, Ensiklopedi Hukum Islam, Jilid II, Ichtiar Baru Van Hoeve, Jakarta.

Dijk, R. Van, 2006, Pengantar Hukum Adat Indonesia, Mandar Maju, Bandung.

Fikri, Ali, 1357 H, Al-Mu'amalat Al-Maddiyah wa Al-Adabiyah, Juz 2.Cet I, Mathba'ah Mushthafa Al-Babiy Al-Halabiy, Mesir.

Fuady, Munir, 2014, Konsep Hukum Perdata, PT, RajaGrafindo Persada, Jakarta.

Hadikusuma, Hilman, 2003, Pengantar Ilmu Hukum Adat Indonesia, Mandar Maju, Bandung.

Holijah, 2017, Analisis Hukum Uang Panjar terhadap konsep dan Praktik Ganti Rugi dalam Transaksi Jual Beli Produk Barang Ekonomi Modern di Indonesia, Noerfikry Refress, Palembang.

Keraf, A. Sonny, 1996, Pasar Bebas Keadilan dan Peran Pemerintah Telaah Atas Etika Ekonomi Adam Smith, Kanisius, Yogyakarta. Nasution, Bahder Johan, 2011, Negara Hukum dan Hak Asasi Manusia, Mandar Maju, Bandung. Pemerintahan Provinsi Sumatera Selatan, 2001, Kompilasi Adat Istiadat Kota Palembang, Meru, Pemerintah Provinsi Sumatera Selatan Subekti dan R.Tjitrosudubio, 2009, Kitab UndangUndang Hukum Perdata, Cet. Ke-9, PT. Pradnya Paramita, Jakarta.

Suratman, et al, 2013, Metode Penelitian Hukum, Alfabeta, Bandung.

Sudiyat, Iman, 2010, Asas-Asas Hukum Adat Bekal Penghantar, Liberty, Yogyakarta.

Asnawi, M. Sobirin, et al, 2007, Hukum Keuangan Islam: konsep, teori dan praktik, Nusamedia, Bandung.

Setiawan, 1999, Pokok-Pokok Hukum Perikatan, Putra Arbardin, Jakarta.

Tutik, Titik Triwulan, 2011, Hukum Perdata dalam Sistem Hukum Nasional, Prenada Media Group, Jakarta.

Tasrif, S., 1987, Bunga Rampai Filsafat Hukum, Abardin, Jakarta.

Zuhaili, Wahbah, 1989, Al-Fiqh Al-Islamiy Wa Adillatuh, Juz IV, Dar Al-Fikr, Damskus.

\section{B. Artikel Jurnal}

Benda-Beckman, Franz Von, et al., "Myths And Stereotypes About Adat Law: A Reassessment Of Van Vollenhoven In The Light Of Current Struggles Over Adat Law In Indonesia," Bijdragen Tot De Taal-, LandEn Volkenkunde, Vol. 167, No. 2-3, 2011.

Innaka, Antari, et al, "Penerapan Asas Itikad Baik", Mimbar Hukum, Volume 24 Nomor 3, Oktober 2012.

Mutiara, Anindya, Ida Fatmawati, Indah Permatasari, "Problematika Penerapan Prosentase Down Payment (Uang Muka) Sebesar 20 \% Pada Kredit Kendaraan Bermotor", Jurnal Private 
Law, Edisi 1 Maret-Juni 2013.

Ramadhan, Choky R., "Konvergensi Civil Law dan

Common Law di Indonesia dalam Penemuan dan Pembentukan Hukum", Mimbar Hukum, Volume 30, Nomor 2, Juni 2018.

Watsons, Alan, "Comparative Law and Legal

Change", The Cambridge Law Journal, Vol. 37, No. 2, November 1978.

\section{Hasil Penelitian/Tugas Akhir}

Aini, Riska, 2017, "Praktek Jual Beli Tanah dengan Memakai Uang Panjar (Uang Muka) di Kecamatan Laguboti Kabupaten Tobasa Propinsi Sumatera Utara (Perspektif Fikih As-Syafi'i dan Fikih Al-Hanbali)", Skripsi, Fakultas Syari'ah dan Hukum UIN Sumatera Utara, Medan.
Holijah, 2014, "Pengintegrasian Urgensi dan Eksistensi Tanggung Jawab Mutlak Produk Barang Cacat Tersembunyi Pelaku Usaha dalam Undang-Undang Perlindngan Konsumen di Era Globalisasi”, Jurnal Dinamika Hukum, Vol. 14 No. 1 Januri 2014. Holijah, 2015, Tanggung Jawab Mutlak Ascetisisme Responsif Subjektif Pelaku Usaha: Konsep Radikal Berbasis Paradigma Hukum Baru sebagai Alternatif Upaya Perlindungan Konsumen terhadap Kerugian Akibat Produk Barang Cacat Tersembunyi di Indonesia, Disertasi, PPS Ilmu Hukum UNSRI, Palembang.

Maghfuroh, Umi, 2010, Tinjauan Hukum Islam terhadap Status Uang Muka dalam Perjanjian Pesanan Catering yang di Batalkan, Skripsi, Fakultas Syari'ah IAIN Walisongo, Semarang. 